\title{
ARS Editorial
}

ano 16

n. 32

A revista Ars, publicação quadrimestral do Programa de Pós-Graduação em Artes Visuais da ECA/USP, busca reunir trabalhos relevantes para o debate das artes e da cultura, produzidos no meio universitário e fora dele, preferencialmente inéditos, com destaque para as artes plásticas. A revista é disponibilizada em formato digital e também em papel, e pretende preservar, com a edição física, um lugar de experimentação gráfica voltado a artistas; a cada número, estes contribuem com intervenções pensadas especialmente para a publicação. Além disso, a partir de 2017, Ars passou a contar com a seção "Escritos de artista”, trazendo experimentos de autores provindos de diversas áreas, que entrelaçam criação artística e literária, à distância da escrita acadêmica ou ensaística.

Ao mesmo tempo em que se abre à produção universitária e ao meio artístico e cultural do país, Ars empenha-se em oferecer textos publicados no circuito internacional - em versão brasileira ou na língua em que foram produzidos - cuja relevância os projete na ordem do dia dos problemas contemporâneos. Sendo uma revista universitária, que procura aglutinar a diversidade de interesses que caracteriza a pós-graduação no país, Ars acothe a eventual ausência de unidade que pode marcar suas pautas como um aspecto produtivo da condição nacional.

Em sua trigésima segunda edição, a revista destina um núcleo especial de textos à obra de Hubert Damisch, teórico falecido em dezembro de 2017. Discípulo de Merleau-Ponty, o autor empreendeu profunda renovação epistemológica na disciplina de história da arte, franqueando-a às contribuições da psicanálise, da filosofia, da antropologia e da semiótica, e conferindo a ela inédita envergadura teórica, para muito além das demarcações tradicionais de competência que a separam da teoria da arte. Dois autores que frequentaram os seminários parisienses de Damisch prestam-lhe homenagem neste número de Ars: Yve-Alain Bois, também ele um teórico cujo trabalho extravasa as demarcações do campo disciplinar, e que manteve com o autor relação de amizade e parceria intelectual desde o início dos anos 1970, e o artista carioca Carlos Zilio, editor fundador da revista Gávea, da PUC do Rio de Janeiro, que pioneiramente divulgou o trabalho do historiador e teórico no Brasil. Destacamos a apresentação, nessa homenagem, da primeira versão brasileira do ensaio de Damisch, “Uma mulher, portanto: Le déjeuner sur l'herbe", análise da obra de Manet, escrita em 1992, na qual o autor assinala

DOI: $10.11606 /$ issn.2178-0447. ars.2018.145093. a reviravolta que essa pintura imprimia à tradição artística, promovendo um encontro desconcertante e dessublimador com o nu feminino. 
Junto a essa seção especial, a publicação apresenta um conjunto de ensaios inéditos produzidos no meio universitário brasileiro ou provenientes de instituições acadêmicas de fora do país, basicamente revendo temas consagrados da história da arte à luz de novos parâmetros conceituais e metodológicos, e movidos pela aspiração de uma revisão crítica da historiografia tradicional da arte. A problemática noção de "primitivo" - e o corolário de termos sob sua alçada ideológica - é revisitada e submetida a um severo ânimo crítico em dois ensaios: "Os primitivos: Mário de Andrade e Georges Bataille", de Larissa Costa da Mata, pós-doutoranda em Literatura Brasileira na USP, e “A contemporaneidade de Bispo", de Kaira Cabañas, da Universidade da Flórida.

Ressaltamos, por fim, a contribuição do artista José Resende, que a nosso convite preparou especialmente para este volume uma edição de trabalhos seus realizados em espaços urbanos. Pareceu-nos oportuno criar um ambiente virtual no qual se cruzassem as esculturas de José Resende e Richard Serra, dois artistas cujas obras questionam provocantemente a escala pública da cidade contemporânea.

\section{Editores}

